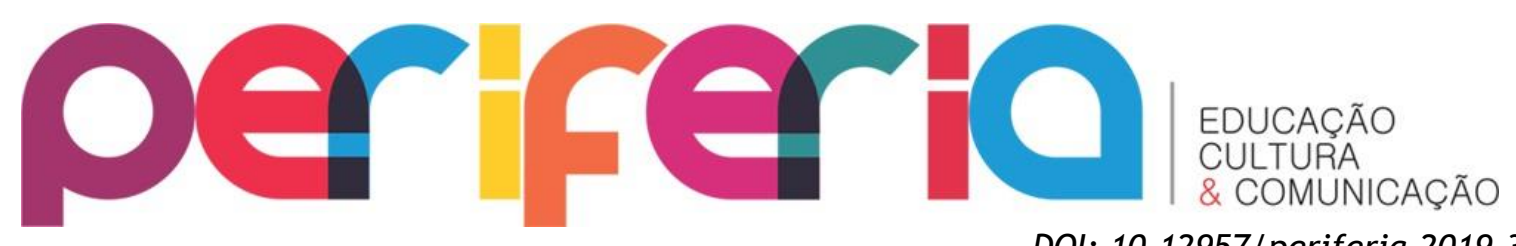

DOI: $10.12957 /$ periferia.2019.36442

\title{
O USO DE MEMES NAS AULAS DE HISTÓRIA
}

\author{
Luisa Quarti Lamarão1 \\ Colégio de Aplicação da Universidade Federal do Rio de Janeiro - CAP/UFRJ
}

\section{Resumo}

Os estudantes da chamada geração virtual, conhecidos como "nativos digitais", apresentam desafios diários às práticas docentes contemporâneas. A constante oferta de informação fora da sala de aula, disponível pela internet, e consequentemente a criação de uma nova forma de linguagem e comunicação entre os alunos, torna importante a discussão sobre novas estratégias em sala de aula. Nesse sentido, o presente trabalho busca relatar uma experiência pedagógica com o uso de memes na elaboração de questões e também na proposta de os próprios alunos criarem seus memes a partir das aulas de História, em turmas de $7^{\circ}$ e $9^{\circ}$ anos do Ensino Fundamental II. Memes são imagens, frases ou vídeos que se reproduzem rapidamente pela internet dada a mensagem e a linguagem atraentes que exibem. $A$ atividade apresentou resultados interessantes, uma vez que, por um lado, atualizou a apresentação das avaliações, já que oferece uma linguagem semelhante àquela que eles estão acostumados em seu cotidiano fora da escola; por outro, colocou os estudantes como produtores de conhecimento, interpretando os temas históricos com seus "olhos cibernéticos". A intenção inicial do projeto era fazê-los enxergar que o conhecimento histórico pode ser trabalhado sob diferentes pontos de vista, inclusive na linguagem viral dos memes. Dessa forma, percebe-se a obsolescência da sala de aula focada numa pedagogia da transmissão, que não enxerga o protagonismo dos estudantes no processo de aprendizagem. Reconhecendo a importância da interatividade nos dias de hoje, torna-se fundamental inserir, de maneira responsável, a linguagem da internet no ambiente escolar.

Palavras-chave: memes; educação básica; ensino de história

\footnotetext{
${ }^{1}$ Professora efetiva do setor curricular de História do Colégio de Aplicação da UFRJ. Doutora em História pela Universidade Federal Fluminense (2012). luisaql@hotmail.com
} 


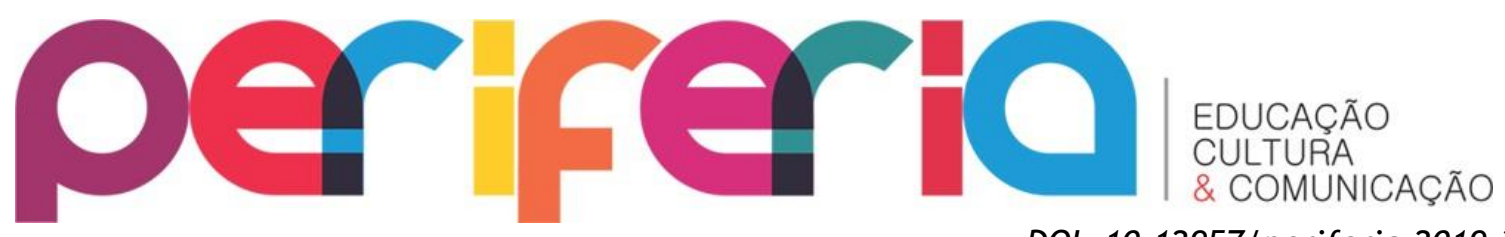

DOI: $10.12957 /$ periferia.2019.36442

THE USE OF MEMES IN HISTORY CLASSES

\begin{abstract}
Students of the so-called virtual generation, known as "digital natives", present daily challenges to contemporary teaching practices. The constant supply of information outside the classroom, available through the internet, and consequently the creation of a new form of language and communication among students, makes it important to discuss new strategies in the classroom. In this sense, the present work seeks to report a pedagogical experience with the use of memes in the elaboration of questions and also in the proposal of the students themselves to create their memes from the History classes, in classes of 7 and 9 years of Elementary School II. Memes are pictures, phrases or videos that reproduce quickly over the internet given the attractive message and language they exhibit. The activity presented interesting results, since, on the one hand, it updated the presentation of the evaluations, since it offers a language similar to the one that they are accustomed in their everyday life outside the school; on the other hand, has placed students as producers of knowledge, interpreting historical themes with their "cybernetic eyes." The initial intention of the project was to make them see that historical knowledge can be worked from different points of view, including in the viral language of memes. Thus, one perceives the obsolescence of the classroom focused on a pedagogy of the transmission that does not see the protagonism of the students in the learning process. Recognizing the importance of interactivity nowadays, it is fundamental to insert, in a responsible way, the language of the internet in the school environment.
\end{abstract}

Keywords: Memes; Basic education; History Teaching 


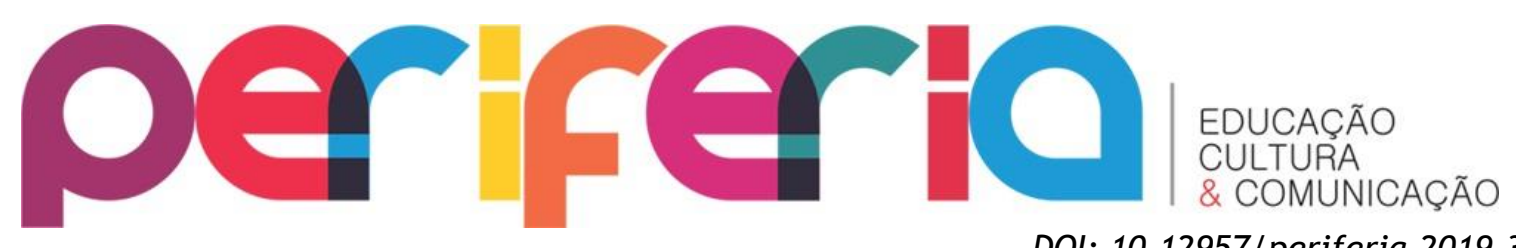

DOI: 10.12957/periferia.2019.36442

EL USO DE MEMES EN LAS CLASES DE HISTORIA

\section{Resumen}

Los alumnos de la llamada generación virtual, conocidos como "nativos digitales", presentan desafíos diarios a las prácticas docentes contemporáneas. La constante oferta de información fuera del aula, disponible por Internet, y consecuentemente la creación de una nueva forma de lenguaje y comunicación entre los estudiantes, hace importante la discusión sobre nuevas estrategias en el aula. En este sentido, el presente trabajo busca relatar una experiencia pedagógica con el uso de memes en la elaboración de cuestiones y también en la propuesta de los propios alumnos a crear sus memorias a partir de las clases de Historia, en grupos de $7^{\circ}$ y $9^{\circ}$ años de la Enseñanza Fundamental II. Memos son imágenes, frases o vídeos que se reproducen rápidamente por Internet dada el mensaje y el lenguaje atractivos que exhiben. La actividad presentó resultados interesantes, ya que, por un lado, actualizó la presentación de las evaluaciones, ya que ofrece un lenguaje semejante a la que ellos están acostumbrados en su cotidiano fuera de la escuela; por otro, colocó a los estudiantes como productores de conocimiento, interpretando los temas históricos con sus "ojos cibernéticos". La intención inicial del proyecto era hacerlos ver que el conocimiento histórico puede ser trabajado bajo diferentes puntos de vista, incluso en el lenguaje viral de los memes. De esta forma, se percibe la obsolescencia del aula enfocada en una pedagogía de la transmisión que no ve el protagonismo de los estudiantes en el proceso de aprendizaje. Reconociendo la importancia de la interactividad en los días de hoy, resulta fundamental insertar, de manera responsable, el lenguaje de Internet en el ambiente escolar.

Palabras clave: Memes; Educación básica; Enseñanza de Historia 


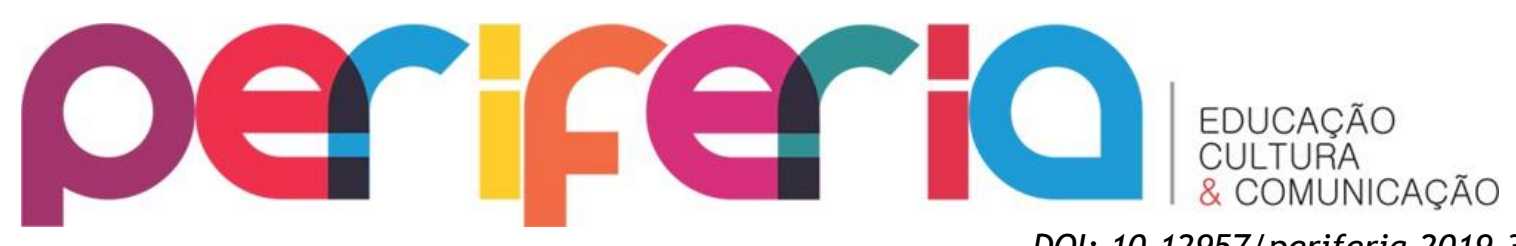

INTRODUÇÃO

DOI: $10.12957 /$ periferia.2019.36442

Se "a interatividade é o pão cada vez mais cotidiano" das sociedades, nas palavras de Edmond Couchot (1997, p. 143), um dos caminhos em sala de aula é tentar "matar essa fome" reconhecendo as inúmeras possibilidades que a linguagem da internet nos propicia. Tentar ficar imune a essa realidade, trabalhando diariamente com jovens, é apenas adiar uma questão que se faz cada vez mais presente no ambiente escolar. Nesse sentido, o artigo pretende apresentar uma discussão sobre o papel da cultura cibernética na educação, e mais especificamente no ensino de História, à luz de diferentes experiências pedagógicas com o uso de memes com alunos de uma escola pública dos $7^{\circ}$ e $9^{\circ}$ anos do Ensino Fundamental II.

Os questionamentos que levaram a elaboração das diferentes propostas pedagógicas aqui apresentadas partiram da ideia de que o espaço de sala de aula cada vez mais se apresenta como um encontro entre os nativos e os imigrantes digitais. Nos termos de Palfrey e Gasser (2011), trata-se, respectivamente, daqueles que já nasceram no contexto em que a comunicação é feita por meio das tecnologias digitais, estando familiarizados com tal linguagem; e aqueles que ainda precisam aprender a lidar com tal cenário por terem nascido em um momento anterior. Como promover então a intersecção entre essas gerações?

Além disso, torna-se necessário pensar em diferentes estratégias que promovam o chamado "reencantamento da educação", como aborda Assman (2012). Para ele, esse processo passa necessariamente pelo diálogo transdisciplinar e pelo desenvolvimento das tecnologias da informação e da comunicação. Dessa forma, o ambiente escolar deve ser prazeroso, conjugando aprendizado e entusiasmo - de estudantes e professores. Portanto, a realidade fora da sala de aula não pode ser excluída das atividades realizadas na escola, pois serão elas que farão a conexão de que o estudante precisa para sentir prazer em aprender.

Entretanto, as dúvidas ainda permanecem. 0 uso das tecnologias a qualquer preço, apenas pelo fato de usá-las, não correspondem ao propósito esperado. Devese entender seu significado para aquele a quem se quer atingir e torná-lo parte integrante do processo de aprendizagem. Em outras palavras: o protagonismo deve 


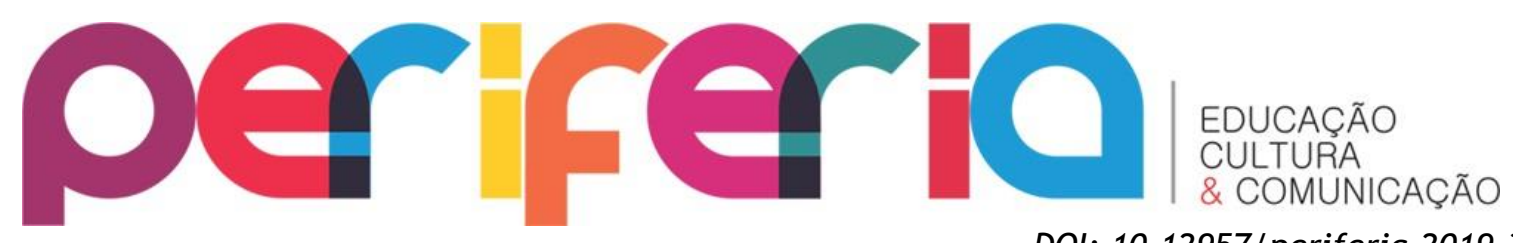

DOI: $10.12957 /$ periferia.2019.36442 ser do/a aluno/a. De nada adianta apresentar as mais avançadas tecnologias de comunicação se aquilo não fizer sentido para o aluno e ele não se sentir parte daquela construção.

Esse novo espaço de comunicação e interação, criado pela rede mundial de computadores, promoveu o desenvolvimento de uma cultura social própria dessa nova realidade, a cibercultura, que, por sua vez, trouxe significativas mudanças nas relações individuais. Os estudantes - nativos digitais, como mencionados anteriormente - já estão inseridos nesses valores desde o nascimento. Portanto, sua relação com o conhecimento também é diferente.

O ciberespaço não tem lugar fixo e a informação contida nele também não; ambos estão sempre presentes, independentemente de sua localização. Estabelece-se assim uma nova relação de tempo e espaço. Onde o professor se encaixa nessa abstração, sendo ele em tese o promotor do conhecimento? Mais uma vez, percebe-se a obsolescência da chamada pedagogia da transmissão. Não há mais transmissores e receptores; há circulação e construção de conhecimento. Os educadores surgem menos como "líderes" do que como mediadores.

Para Gadotti, "o ciberespaço rompeu com a ideia de tempo próprio para a aprendizagem.[...] o tempo de aprender é hoje e sempre." (2000, p.8). Reconhecendo tal realidade, percebe-se a importância de novas tecnologias que afetem positivamente o estudante, modificando e ampliando as maneiras de aprender e ensinar. Os memes, a nova linguagem de comunicação que une texto e imagem, configura-se como uma interessante ferramenta nesse sentido.

\section{MEMES}

O ciberespaço permitiu que a produção de conteúdo se multiplicasse. A comunicação, presente agora em todos os espaços e momentos da vida, não se faz mais apenas por profissionais da área, mas também por amadores (das mais variadas idades), que veem naquele cenário a oportunidade de compartilhar rapidamente suas produções. Assim, ele consome e produz conteúdo - muitas vezes ao mesmo tempo - que pode ser uma foto, um texto, um desenho, um vídeo. Informação. E como transformá-lo em conhecimento? 


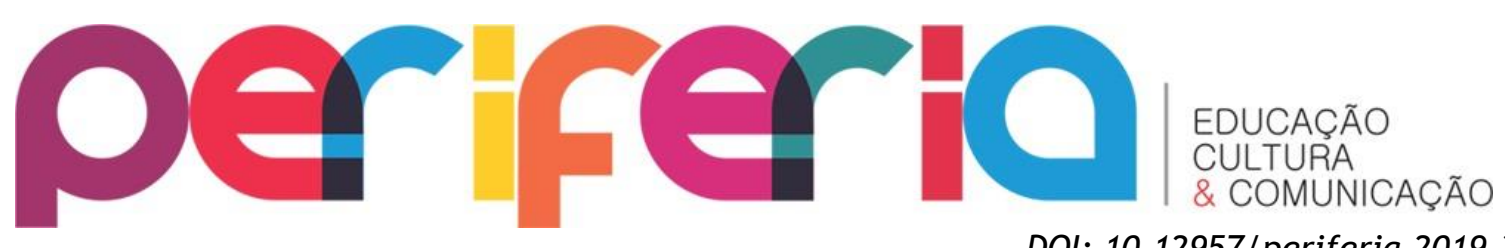

DOI: $10.12957 /$ periferia.2019.36442

Os memes são uma dessas formas de conteúdo compartilhado pela internet que, por seu caráter bem-humorado e também crítico, são reproduzidos e chegam a milhares de pessoas com grande velocidade. Como histórias que são contadas ao longo do tempo; aquelas que chamam mais atenção permanecem, e são passadas de geração em geração. Nas palavras de Juliana Xavier de Araújo

Os memes não são somente reproduzidos, mas sim reelaborados de acordo com a situação e o contexto social vivido pelo sujeito. É um processo criativo de receber e dar sentido a essas formas contextualizando-as, ou seja, cada indivíduo utiliza o sentido do meme e o ressignifica continuamente em cada replicação a fim de compartilhar novos enunciados e adquirir um determinado capital social. (ARAÚJO, 2012, p. 17)

Nesse sentido, é interessante destacar que a pesquisadora Susan Blackmore concluiu que o meme é "tudo aquilo que você aprendeu de outra pessoa através da imitação" (2000, p. 6). Assim, "podem ser considerados como unidades de construção do conhecimento e de práticas de aprendizagem”. (ARAÚJO, 2012, p. 14) Por que não utilizá-los como instrumentos pedagógicos?

Piaget, um dos mais importantes estudiosos do campo da educação, defende que o sujeito é um organismo constituído de estruturas que respondem aos estímulos do meio, e logo todo pensamento se origina na ação. Para ele, o desenvolvimento intelectual ocorre na incessante busca pelo equilíbrio entre a assimilação e a acomodação do conhecimento. Parte da proposta que será aqui desenvolvida é de que os memes sejam produzidos pelos alunos como uma nova forma de resposta a sua assimilação do conhecimento. A partir desse raciocínio, pode-se destacar a relevância do uso da linguagem da internet como um caminho - e não um fim - na produção de conteúdos que despertem a curiosidade nos alunos.

Vemos então a possibilidade de pensar uma prática pedagógica diferente e contrária àquelas que defendiam a simples transmissão de conhecimentos para os estudantes, considerados nesse cenário como "folhas em branco". (BORDENAVE, 1983, p. 29) Desconsiderar sua capacidade autoral é remar contra uma maré de construção coletiva de conhecimento. Nesse sentido, é importante lembrar que 


\section{periferio}

DOI: $10.12957 /$ periferia.2019.36442

$\mathrm{Na}$ sociedade da informação, a escola deve servir de bússola para navegar nesse mar do conhecimento, superando a visão utilitarista de só oferecer informações "úteis" para a competitividade, para obter resultados. Deve oferecer uma formação geral na direção de uma educação integral. 0 que significa servir de bússola? Significa orientar criticamente, sobretudo as crianças e jovens, na busca de uma informação que os faça crescer e não embrutecer. (GADOTTI, 2000, p. 8)

\section{ATIVIDADES PEDAGÓGICAS COM OS MEMES}

Inicialmente, o uso de memes foi pensado apenas nas avaliações periódicas do $7^{\circ}$ e $9^{\circ}$ anos do Ensino Fundamental II, como testes e provas. Em função do reduzido tempo para a realização das mesmas - 50 minutos, em geral - e, principalmente, do reconhecimento das transformações nas formas de leitura entre os estudantes de hoje em dia, esse recurso parecia encaixar-se a essas duas demandas do ambiente escolar em questão. É inegável que o desenvolvimento das tecnologias fez com que o acesso facilitado às informações tornasse, para muitos jovens, o hábito da leitura "menos necessário". Aqui defende-se que a forma de ler mudou, mas o interesse pelo conhecimento entre a juventude, se devidamente estimulado, irá sempre existir.

Assim, no lugar de textos históricos que muitas vezes não despertavam o interesse no jovem, foram inseridos os memes em alusão a algum processo histórico estudado.

Imagem 1

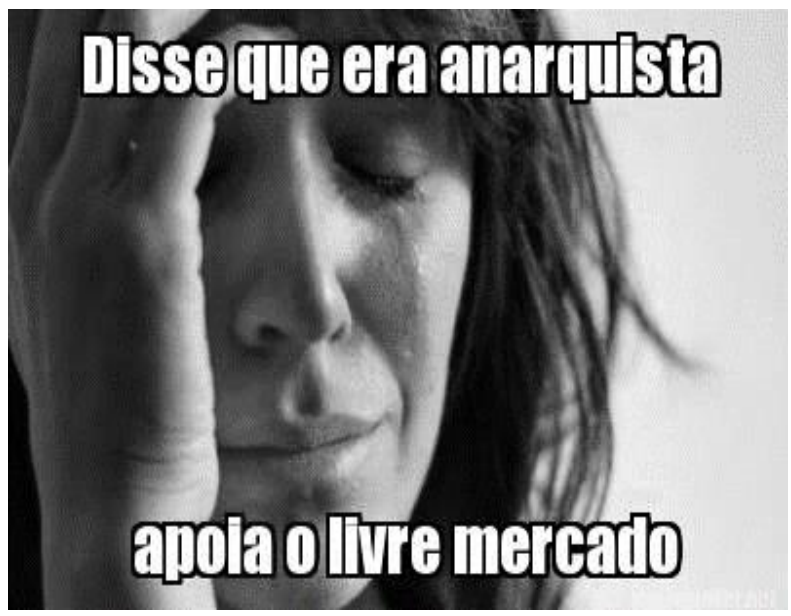




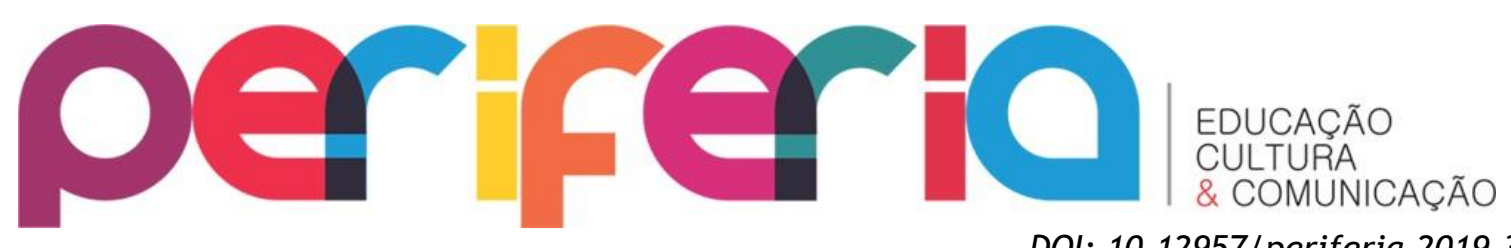

A partir dessa nova linguagem, os enunciados eram elaborados. No caso específico do meme acima, foi perguntado qual seria o motivo para a aparente tristeza da mulher na imagem. A expectativa era de que ele mobilizasse as contradições de se defender o anarquismo e o livre mercado, uma vez que um anula o outro. Havia, portanto, a preocupação em colocar o meme como ponto de partida da discussão e não apenas ilustração do tema. Como essa nova linguagem demanda uma interpretação da junção imagem-texto, muitas vezes carregada de ironia, a questão tornava-se mais um exercício de leitura de mundo do que uma simples cópia de um conteúdo memorizado.

Dessa forma, o estudante identificava-se com a fonte em questão, estimulando seu envolvimento com a elaboração da resposta. Além disso, foram inúmeras as risadas durante a realização das avaliações. Aparentemente, eles eram afetados por aquele novo e até então diferente documento presente nas avaliações. Quando questionados sobre os risos, afirmavam unanimemente que não imaginavam ver em uma prova algo que estavam acostumados a ver apenas no computador ou no celular, fora da escola. Como não considerar esse fator um importante elemento pedagógico? Com a palavra, mais uma vez, Moacir Gadotti:

\begin{abstract}
A escola está desafiada a mudar a lógica da construção do conhecimento, pois a aprendizagem agora ocupa toda a nossa vida. E porque passamos todo o tempo de nossas vidas na escola - não só nós, professores - devemos ser felizes nela. A felicidade na escola não é uma questão de opção metodológica ou ideológica, mas sim uma obrigação essencial dela. Como diz Georges Snyders (1998) no livro A alegria na escola, precisamos de uma nova "cultura da satisfação", precisamos da "alegria cultural". O mundo de hoje é "favorável à satisfação" e a escola também pode sê-lo. (2012, p. 8)
\end{abstract}

O pesquisador Snyders, mencionado acima, defende que é possível fazer uma síntese entre as pedagogias tradicional e moderna, conjugando o que as duas tem de positivo, possibilitando a formação plena do indivíduo. Para tanto, este deve se sentir realizado (ter alegria) e capaz de superar as contradições da sociedade. Se por um lado, reafirma a importância dos modelos educacionais e da figura do professor 


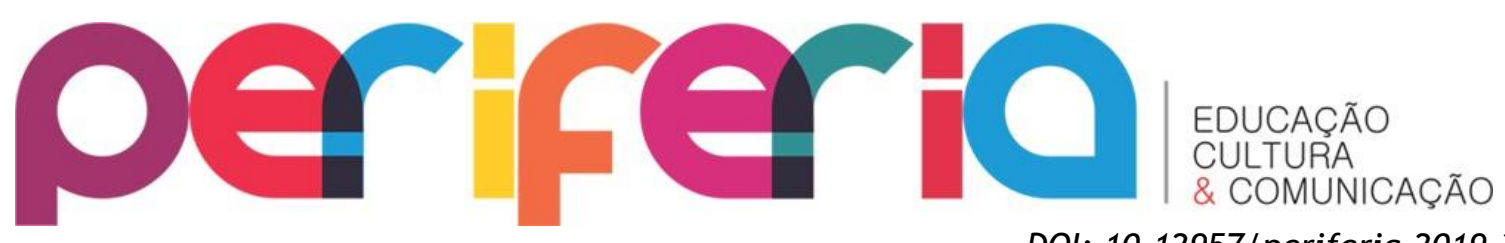

DOI: $10.12957 /$ periferia.2019.36442 presentes na pedagogia tradicional, critica os conteúdos selecionados nessa realidade. Por outro lado, o autor argumenta que

Aquilo que existe de muito importante na pedagogia nãodiretiva é o desejo da felicidade do aluno, (...). Mas o que nessa pedagogia me parece perigoso é o risco de conformismo, porque o desejo dos alunos não vai, por si próprio, além dos seus limites de classe social, bem como um risco de cepticismo, por não se ousar, não se poder ousar, fazer com eles um trabalho de aprofundamento e desmascaramento das ideologias. O meu sonho consistiria em unir os valores positivos da pedagogia não-diretiva a um processo que jogaria também com os conteúdos do ensino e com as ideias de que os alunos devem se apropriar. (SNYDERS, 1984 APUD CARVALHO, 1999, pp. 156-157)

Nessa perspectiva, trabalhar com a linguagem a que o estudante está mais acostumado - a da internet - mas promover, a partir disso, desafios relacionados aos conteúdos mobilizados, é uma forma de tirá-los dessa "zona de conforto" a que Snyders faz referência de maneira indireta, quando menciona a problemática de uma pedagogia exclusivamente voltada para a felicidade do/a aluno/a. Mais do que "felizes", os estudantes querem ser desafiados.

A partir do sucesso dessa primeira tentativa, os estudantes demandaram mais atividades relacionadas à cibercultura. A avaliação seguinte foi elaborada, do início ao fim, com enunciados que apresentavam memes. Um deles apresentava a imagem de Napoleão Bonaparte, com os seguintes dizeres: "Você acha que R\$0,20 não é motivo para ir às ruas e mudar tudo, sabe qual foi o estopim para a Revolução Francesa? O preço do pão." O discente deveria explicar historicamente esse motivo para a eclosão da revolução e também analisar o protagonismo das camadas populares em momentos históricos de ruptura.

Temos assim mais um exemplo de uma proposta que provoca os estudantes, pois articula um evento com grande repercussão na mídia - as manifestações populares do ano de 2013, que originalmente teriam ocorrido em função do aumento abusivo de $\mathrm{R} \$ 0,20$ das passagens de ônibus - ao processo histórico mundialmente conhecido que ocorreu na França e inaugurou a Idade Contemporânea. Dessa forma, abre-se espaço para reflexões sobre o conceito de revolução e o caráter dos agentes históricos, comumente associados aos chamados "grandes homens". E mais: desfaz 


\section{periferio}

DOI: $10.12957 /$ periferia.2019.36442

a ideia difundida com frequência de que a disciplina curricular História trata apenas de temas antigos e "mumificados", sem relação com o presente.

Ainda nessa perspectiva, nas aulas sobre a Revolução Industrial para o $9^{\circ}$ ano, foram distribuídas diferentes imagens sobre o tema e foi requisitado que - agora em sentido contrário ao ocorrido nas avaliações individuais - em grupos eles próprios elaborassem seus memes a partir das discussões sobre o processo e as consequências sociais da industrialização inglesa do século XVIII. O resultado mais emblemático dessa atividade foi o trabalho que colocou como legenda o termo "Belas, recatadas e do lar" para uma imagem de mulheres operárias em greve na Europa. Sem deixar de mobilizar o conteúdo histórico, mas dando o toque irônico e crítico próprio dos memes, os estudantes atualizaram, em uma imagem, discussões sobre feminismo e luta operária. ${ }^{2}$

No $7^{\circ}$ ano, em função da reduzida carga horária de dois tempos semanais de 50 minutos (um tempo semanal a menos do que o $9^{\circ}$ ano), a atividade teve de ser planejada com sua execução em casa, fugindo, em tese, ao "controle" do professor. Para tanto, foram disponibilizadas imagens relativas ao tema discutido naquela semana de aula, e, em suas residências, os estudantes deveriam elaborar seus memes, como atividade extra, não obrigatória. Houve o receio inicial de que eles não só não se envolvessem com tal tarefa, como também se utilizassem do nada honesto recurso da cópia. Porém, contra essas pessimistas expectativas, eles entregaram diferentes memes, sem nenhuma cobrança extra e dentro do prazo - algo que em outros momentos e para outras atividades nem sempre ocorria.

A temática do trimestre em questão era a Idade Moderna: a expansão marítima europeia, os processos de colonização das Américas e o sistema escravista colonial. Tradicionalmente, tais temas não despertavam interesse das turmas, que frequentemente perguntavam o que aquilo tinha a ver com suas vidas. Era como se o passado fosse uma ilha a que eles não tinham acesso nem interesse em conhecer.

\footnotetext{
${ }^{2}$ A expressão "Bela, recatada e do lar" foi utilizada na matéria da revista Veja de 18 de abril de 2016, referindo-se a esposa do presidente Michel Temer, Marcela Temer, causando grande polêmica, principalmente entre o movimento feminista. 0 pretenso elogio à primeira-dama foi visto como uma maneira machista e simplista de se referir às mulheres. Logo, tal debate ganhou grande espaço nas redes sociais e, consequentemente, na produção de diferentes memes sobre a temática e com o uso da expressão.
} 


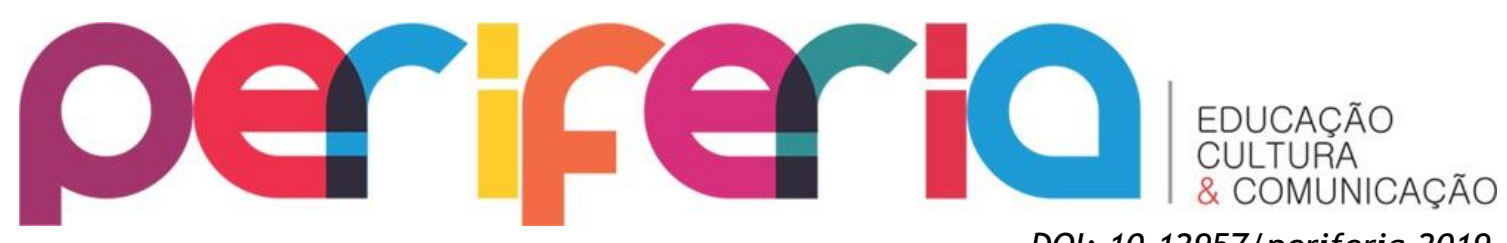

DOI: $10.12957 /$ periferia.2019.36442

Um dos desafios do professor de História do Ensino Fundamental II é conseguir estabelecer conexões dos conteúdos com a atualidade. A faixa etária desse segmento - entre 11 e 15 anos, aproximadamente - é ainda muito curiosa, mas de maneira geral, sua capacidade de abstração é ainda reduzida. Portanto, faz-se necessária tornar o conteúdo mais “palpável”. Muitas estratégias bem-sucedidas já haviam sido realizadas, como uso de filmes, debates, júri simulados, mas o uso dos memes talvez tenha mobilizado o maior número de alunos simultaneamente, pois foi uma atividade em que eles podiam pensar e executar em qualquer momento de suas vidas, já que o celular e/ou o computador - importante frisar que naquela realidade escolar específica - estavam sempre por perto. É preciso destacar que nessa atividade foi cobrada a presença das discussões históricas, mas também da ironia e/ou crítica típicas dos memes. Diferentes competências eram ali testadas e eles gostaram disso.

Os resultados foram extremamente interessantes e muitos foram utilizados como material para as avaliações posteriores. Grande era a alegria de muitos deles verem seus memes presentes como ponto de partida para os enunciados das avaliações. Sentiam-se mais seguros e confiantes na elaboração das respostas. E nesse momento o ciclo se fechava, pois os alunos viam-se como protagonistas do processo de aprendizagem, em uma culminância de todo o processo de discussão dos conteúdos históricos: eram ao mesmo tempo produtores e consumidores desse conhecimento.

\section{Imagem 2}




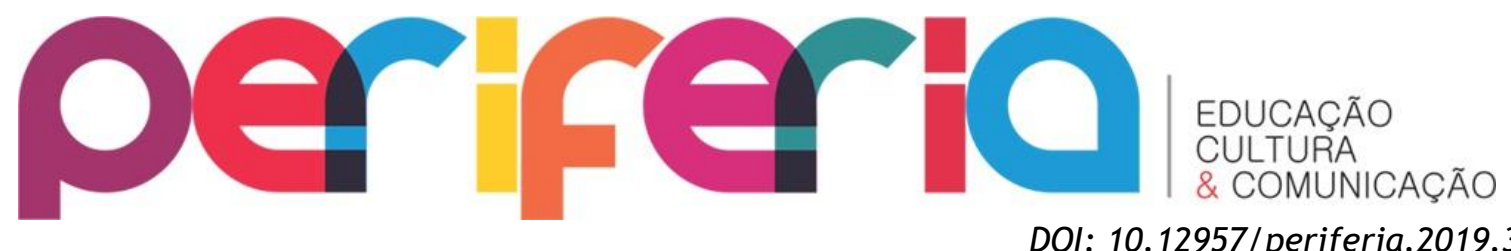

DOI: $10.12957 /$ periferia.2019.36442

Brasil, acharion on descoberto?

\section{Eis a questão}

Imagem 3

\section{O OLhar guROPEU}

\section{SOBRE OS GSORAVOS}




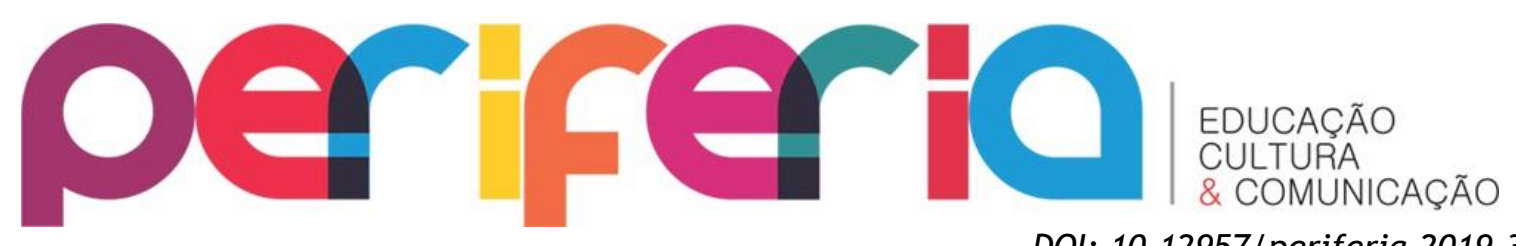

\section{CONSIDERAÇÕES FINAIS}

DOI: $10.12957 /$ periferia.2019.36442

Embora as práticas pedagógicas aqui apresentadas estejam em seu estágio inicial, com menos de dois anos de execução, já apresentaram efeitos que ultrapassaram aqueles mencionados no corpo do presente texto. Para além da surpresa, satisfação e envolvimento dos estudantes com as propostas, foi percebido também um maior interesse nas aulas propriamente ditas, uma vez que foram criadas expectativas sobre as próximas atividades que seriam apresentadas e das quais eles seriam protagonistas.

A curiosidade - este "motor" tão especial e presente nas crianças deste segmento - sobre os conteúdos de História ressurgiu, atraindo até alunos que de maneira geral não tinham tanto interesse pela disciplina, já que eles se viram desafiados a pensar em novas linguagens sobre os fatos históricos. Assim, a conexão entre "nativos" e "imigrantes" digitais estava em curso, seguindo um fluxo de constante troca entre os envolvidos.

Logo, em consonância com os novos estudos sobre ensino de História, que buscam diferentes formas de apresentação de conteúdos considerados "cristalizados", o uso de memes possibilita que os próprios alunos usem sua experiência, seu "olhar cibernético" para interpretar processos históricos. Considerando que o estudo da História ocorre a partir da análise e interpretação das fontes, por que não considerar os memes, eles próprios, um novo tipo de documento histórico? Futuramente, eles serão usados como tal e os alunos envolvidos na atividade aqui apresentada estão, desde já, deixando seu legado.

\section{REFERÊNCIAS}

ARAÚJO, Juliana Xavier de. Memes: a linguagem da diversão na internet. Análise dos aspectos simbólicos e sociais dos Rage Comics. 86 pps. Monografia final do curso de Comunicação Social/Jornalismo da Universidade Federal do Rio de Janeiro. Rio de Janeiro, 2012.

ASSMANN, Hugo. Reencantar a educação: rumo a sociedade aprendente. Petrópolis: Vozes, 2012. 


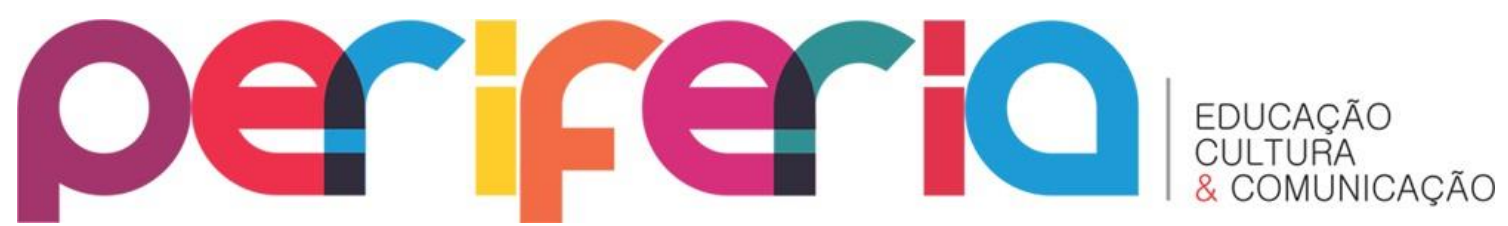

DOI: $10.12957 /$ periferia.2019.36442

BLACKMORE, Susan. The Meme Machine. Oxford, Reino Unido: Oxford University Press, 2000.

BORDENAVE, Juan E. Dias. Alguns fatores pedagógicos. Texto traduzido e adaptado do artigo La Tranferencia de Tecnologia Apropriada ao Pequeño Agriculor. Bordenava Juan E. Dias. Revista Interamericana de Educação de Adultos, vol. 3, no 1-2 - PRDE OEA. Por Maria Thereza Grandi, OPS. Brasília, 1983. Disponível em http://www.fo.usp.br/wp-content/uploads/EAlguns.pdf. Acesso em 30.07.2018.

CARVALHO, Roberto Muniz Barretto. "Georges Snyders: em busca da alegria na escola.” In: Perspectiva. Florianópolis, v.17, n. 32, p.151-170 jul./dez. 1999.

COUCHOT, E. A arte pode ainda ser um relógio que adianta? 0 autor, a obra e o espectador na hora do tempo real. In: DOMINGUES, D. (org.) A arte no século XXI: $a$ humanização das tecnologias. (org.). São Paulo: FAPESP, 1997.

GADOTTI, MOACIR. Perspectivas atuais da educação. In: São Paulo em Perspectiva, São Paulo, v. 14, n. 2, pp. 03-11, Junho/2000.

LÉVY, Pierre. Cibercultura. São Paulo: Ed.34, 2005.

PALFREY, John; GASSER, Urs. Nascidos na era digital: entendendo a primeira geração dos nativos digitais. Porto Alegre: Artmed, 2011.

PIAGET, Jean. Biologia e Conhecimento. Vozes: Petrópolis, 1996.

SOFFNER, Renato Kraide; KIRSCH, Deise Becker. Educação na cibercultura: as tecnologias da inteligência e a práxis educativa". Revista Intersaberes, Curitiba, vol. 9, n.8, p. 220 - 228, jul. - dez. 2014. 